\title{
BABY WITH A TAIL
}

\author{
BY \\ HUGH JOLLY* \\ From the Department of Paediatrics, University College, Ibadan, Nigeria
}

(RECEIVED FOR PUBLICATION DECEMBER 17, 1962)

\begin{abstract}
A female Yoruba infant was admitted to University College Hospital, Ibadan, on November 17, 1961, at the age of 1 day, on account of a tail. The child had been born at home and was full term. The mother, who is the junior of two wives, had received three injections during pregnancy for the treatment of anaemia. No other history of drugs was obtained and she had not been exposed to $\mathrm{X}$ rays. Her two other children were normal.

On admission the baby was found to be normal apart from the features shown in the illustrations (Figs. 1-4). A tubular cord covered with normal skin arose from the midline of the back at the level of L 3-4. It passed anteriorly round the right flank to be attached to the anterior abdominal wall in the right iliac fossa. Apart
\end{abstract}

* Present address: Charing Cross Hospital, London. from its attachments at front and back, the cord lay free and felt uniformly soft. The cord can be seen to be thicker in the portion nearest the spine.

In addition to the tail there were other malformations. Two deep ring constrictions were present on theleft leg(Fig. 4), and there was hypoplasia of the toes of the left foot. A less deep ring constriction was present on the outer aspect of the right lower leg and this was associated with syndactyly of the 4th and 5th toes of the same foot. It seems possible that these grooves caused impairment of blood supply to the developing feet with consequent malformation. Browne (1957) is of the opinion that congenital ring constrictions are due to thrusting of the limb through the amniotic membranes. This seems to be a more likely explanation than an 'amniotic band' which would need to form a loop in order to produce such constriction.

The only other abnormality was generalized scaling

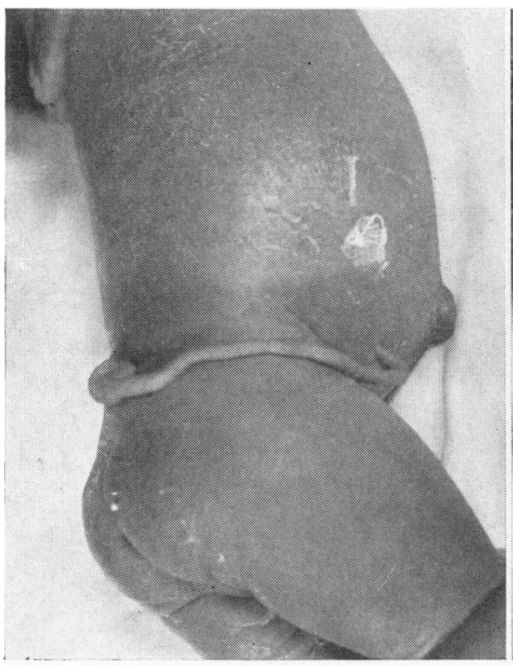

Fig. 1

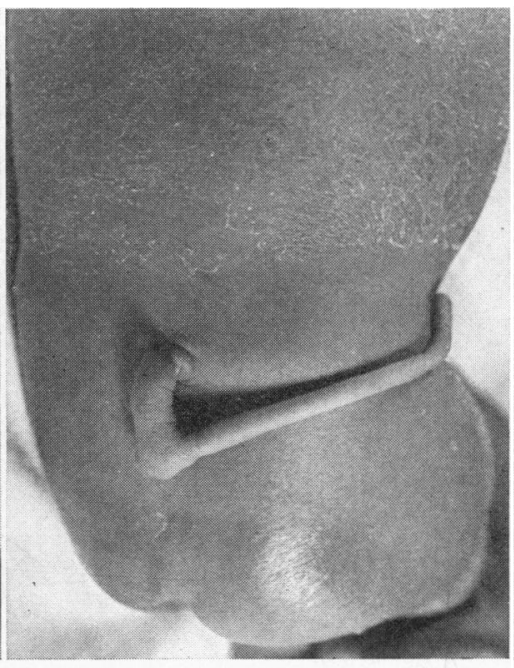

Fig. 2

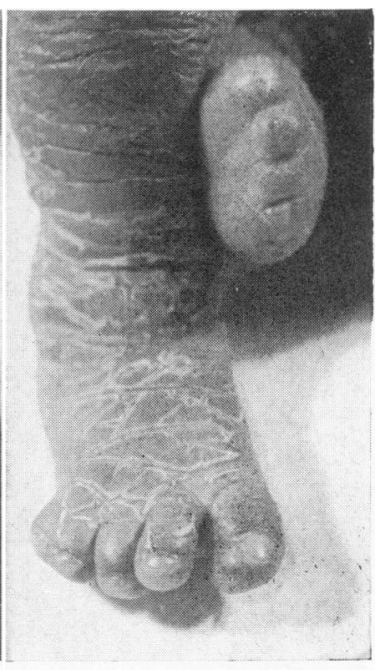

Fig. 3

Figs. 1 and 2-Views of trunk to illustrate the anterior and posterior attachments of the tail which lay free between these points.

Fig. 3-Right foot shows syndactyly of the 4th and 5 th toes, associated with constriction just above the ankle. Left foot shows hypoplasia of all toes, which was associated with two deep ring constrictions in the lower leg. The scaling of the skin can be seen. 


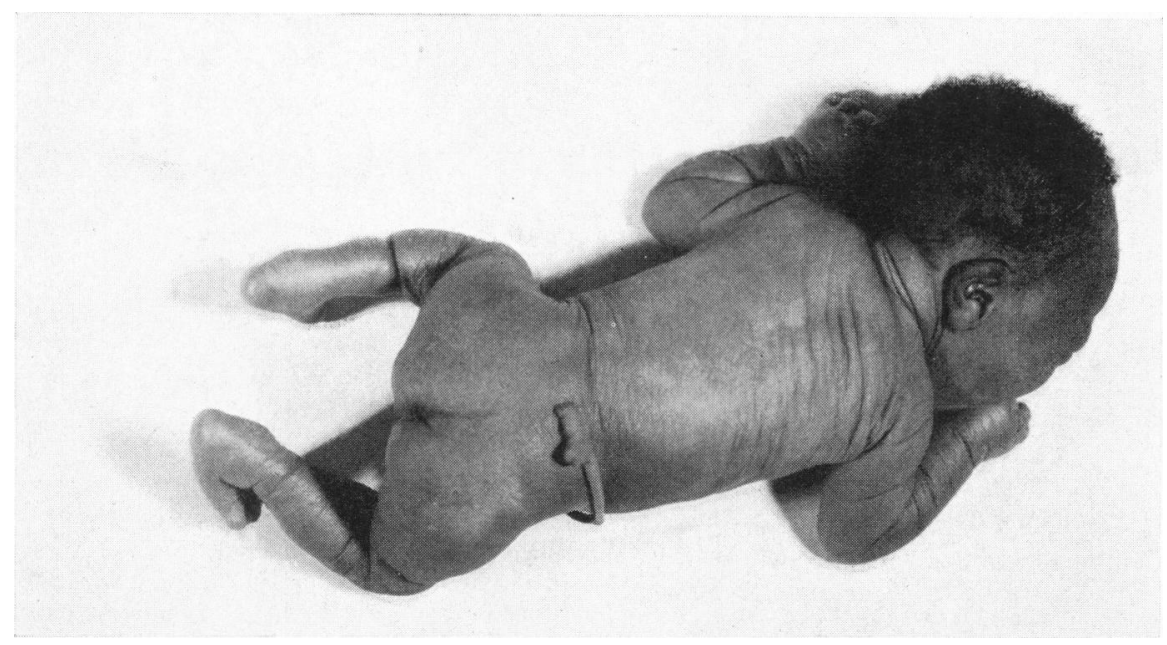

Fig. 4-Back view. One deep ring constriction below the left knee is well shown.

of the skin, of the type often seen in postmature infants. Radiographs of the lumbar spine and right foot were normal but a radiograph of the left foot showed only the proximal phalanges to be present.

The tail was removed on December 4, 1961, by $\mathrm{Mr}$. Geoffrey Walker and no connexion with the deeper structures was found. Examination of the specimen and sections from different sites was reported by Dr. J. G. Jackson as follows:

'The specimen consists of a piece of skin, circular in cross-section and $13 \mathrm{~cm}$. in total length. It is $1 \mathrm{~cm}$. in diameter at its maximum and $0.5 \mathrm{~cm}$. at its minimum. The epidermis is of normal appearance and is keratinized. The underlying dermis shows apparently normal collagen in which there are sweat glands and ducts. Towards the centre, the specimen consists of fibro-fatty tissue only. Nerve fibres are present in fairly large numbers. There also appears to be a central core of collagenous tissue running the whole length of the specimen. Further stains have not revealed any other features.'

\section{Discussion}

In medical literature there are many reports of human tails, and earlier writings are summarized by Gould and Pyle (1897). However, no case has been found in which the tail was attached at both ends as in this child. It seems possible that the tail represents a very poor attempt at the formation of a twin, in view of the central core of collagenous tissue and the presence of nerve fibres. No explanation can be offered for its attachments.

\section{Summary}

A report is given of a newborn infant possessed of a tail, one end of which was attached to the lumbar region and the other to the anterior abdominal wall. Histological examination showed the presence of a central core of collagenous tissue and of nerve fibres. It is suggested that this is a parasitic foetus.

I am indebted to Dr. Balogun of Ikeja General Hospital who originally referred the case, and to Mr. Frank Speed of the Department of Medical Illustration, University College, Ibadan, for the photographs.

\section{REFERENCES}

Browne, D. (1957). The pathology of congenital ring constrictions. Arch. Dis. Childh., 32, 517 .

Gould, G. M. and Pyle, W. L. (1897). Anomalies and Curiosities of Medicine, p. 277. Saunders, Philadelphia; Rebman Publishing Co., London. 